\title{
AKTYWNOŚĆ GOSPODARCZA NA MIGRACYJNYCH I NIEMIGRACYJNYCH OBSZARACH WIEJSKICH WOJEWÓDZTWA OPOLSKIEGO
}

\section{ECONOMIC ACTIVITY AMONG INHABITANTS OF MIGRATORY AND NON-MIGRATORY RURAL AREAS OF THE OPOLSKIE VOIVODSHIP}

\author{
Diana ROKITA-POSKART \\ Politechnika Opolska \\ Wydział Ekonomii i Zarządzania, Katedra Polityki Regionalnej \\ ul. Luboszycka 7, 45-036 Opole \\ d.rokita@po.opole.pl
}

\begin{abstract}
Zarys treści: Obszary wiejskie województwa opolskiego przez ostatnich kilka dekad przeszły szereg przemian, które wywarły istotny wpływ na ich obecną sytuację społeczno-gospodarczą. Kluczowe znaczenie w procesie transformacji obszarów wiejskich regionu miały intensywne procesy migracji zewnętrznych części ludności Opolszczyzny, która za sprawą posiadania oprócz polskiego, także niemieckiego obywatelstwa czy pochodzenia, miała możliwość pracy i wyjazdu do krajów Europy Zachodniej jeszcze przed akcesją Polski do Unii Europejskiej. W obliczu tych intensywnych procesów migracji, w których w przeszłości uczestniczyła głównie ludność rodzima Śląska, na obszarach wiejskich regionu obserwowano silne przeobrażenia demograficzne, społeczne oraz gospodarcze. Mając powyższe na uwadze, celem zaprezentowanej w niniejszym artykule analizy porównawczej stało się określenie wpływu emigracji zarobkowej ludności regionu na jeden z elementów określających sytuację ekonomiczną obszarów wiejskich - na aktywność gospodarczą gmin wiejskich województwa opolskiego mierzoną wskaźnikiem liczby osób fizycznych prowadzących działalność gospodarczą na 100 mieszkańców. W wyniku tej analizy ustalono, że emigracja zarobkowa może mieć związek z aktywnością gospodarczą mieszkańców obszarów wiejskich, aczkolwiek jest ona determinowana jeszcze przez szereg innych czynników.
\end{abstract}

Słowa kluczowe: aktywność gospodarcza, przedsiębiorczość, obszary wiejskie, województwo opolskie.

\section{Wstęp}

Województwo opolskie jako najmniejsze województwo w Polsce stanowi obszar wyjątkowy nie tylko w kraju, ale również w Europie. Bez wątpienia specyfika ta wynika ze skali emigracji zarobkowej jego mieszkańców, będącej w pewnym sensie konsekwencją zamieszkania na części obszarów wiejskich rodzimej ludności śląskiej․ Znaczna część tych osób poprzez

${ }^{1}$ Określenia rodzima ludność śląska oraz ludność autochtoniczna będą w niniejszym opracowaniu traktowane zamiennie. Przez określenia te rozumie się osoby pochodzenia miejscowego, które zgodnie z obowiązującym prawem niemieckim zachowały obywatelstwo niemieckie lub prawo do niego. 
uwarunkowania historyczne zachowała prawo do posiadania obywatelstwa niemieckiego i jeszcze przed akcesją Polski do Unii Europejskiej miała swobodę w podejmowaniu pracy, zarówno w Niemczech, jak i w innych państwach ówczesnej Unii Europejskiej, co bezpośrednio wpłynęło na ich większą aktywność migracyjną. Emigracja zarobkowa mieszkańców województwa opolskiego, w której do niedawna jeszcze masowo uczestniczyły osoby posiadające niemieckie pochodzenie, pociąga za sobą szereg konsekwencji społeczno-ekonomicznych zarówno dla całego regionu, jak i w szczególności dla jego obszarów wiejskich. Jedną z nich jest wpływ emigracji zarobkowej na aktywność gospodarczą. Z jednej strony emigracja prowadzić może do wzrostu liczby przedsiębiorstw zaspokajających popyt konsumpcyjny oraz inwestycyjny generowany napływem dochodów z pracy za granicą (Jończy 2010, s. 265-267; Wpływ emigracji zarobkowej... 2007, s. 24-27). Ponadto z wyjazdami zarobkowymi może być związana również większa aktywność w zakresie zakładania przedsiębiorstw przez migrantów powrotnych, którzy po reemigracji do miejsca pochodzenia transferują wiedzę oraz zdobyty za granicą kapitał finansowy (Poskart 2013, s. 195), społeczny i zawodowy (Solga 2013, s. 158-161). Z drugiej jednak strony, emigracja zarobkowa prowadzić może do ograniczenia aktywności gospodarczej na obszarach pochodzenia migrantów, co uwarunkowane jest odpływem za granicę osób przedsiębiorczych, które, gdyby nie wyjazd, mogłyby teoretycznie rozpocząć działalność gospodarczą w miejscu swego pochodzenia (Solga 2013, s. 162-163, Okólski 2011, s.16, Klemens 2014, s. 105-106). Pejoratywne oddziaływanie emigracji może być widoczne również w mniejszej liczbie przedsiębiorstw funkcjonujących na lokalnym rynku w związku z mniejszym popytem konsumpcyjnym oraz ograniczoną podażą pracy. Z emigracją bowiem związany jest ubytek nie tylko konsumentów, ale również potencjalnych pracowników, których deficyt wpływać może na decyzje dotyczące lokalizacji przedsiębiorstw.

W związku z możliwością wieloaspektowego oddziaływania emigracji na aktywność gospodarczą w artykule dokonano analizy wpływu emigracji zarobkowej na przedsiębiorczość na obszarach wiejskich województwa opolskiego. W pierwszej kolejności zaprezentowano przegląd literatury oraz badań nad zależnością pomiędzy emigracją zarobkową oraz migracją powrotną a aktywnością gospodarczą. W dalszej części artykułu porównano wartości wskaźnika aktywności gospodarczej mierzonego liczbą osób fizycznych prowadzących działalność gospodarczą do liczby mieszkańców w dwóch wyodrębnionych umownie grupach gmin wiejskich Opolszczyzny² - w gminach charakteryzujących się dużą skalą emigracji zarobkowej nazwanych umownie gminami migracyjnymi, oraz w gminach charakteryzujących się małą skalą emigracji zarobkowej nazwanych umownie niemigracyjnymi. Warto w tym miejscu zaznaczyć, że przy podziale gmin województwa opolskiego korzystano z wyników badań empirycznych, celowo pomijając dane statystyczne, bowiem uważa się, że obecna sprawozdawczość procesów migracji w Polsce nie jest precyzyjnym źródłem danych (Jończy 2010, s. 54; Latuch 1985, s. 307; Iglicka-Okólska 1999, s. 10). Biorąc zatem pod uwagę wyniki badań (Jończy 2010, s. 54; Rauziński i Szczygielski 2008, s. 124) prowadzonych na terenie województwa opolskiego, wyodrębniono 34 gminy charakteryzujące się nasiloną skalą emigracji zarobkowej: Biała, Bierawa, Chrząstowice, Cisek, Dąbrowa, Dobrodzień - obszar wiejski, Dobrzeń Wielki, Gogolin - obszar wiejski, Izbic-

\footnotetext{
${ }^{2}$ Na potrzeby niniejszego opracowania pojęcia Opolszczyzna oraz województwo opolskie używać się będzie zamiennie, mimo że dwie gminy obecnego obszaru województwa - Praszka i Rudniki - przyłączone po reformie 1999 r., nie stanowią historycznego terenu Śląska, a poza obszarem województwa opolskiego pozostają tereny powiatów raciborskiego i lublinieckiego przynależne do historycznego obszaru Śląska Opolskiego.
} 
ko, Jemielnica, Kolonowskie - obszar wiejski, Komprachcice, Krapkowice - obszar wiejski, Lasowice Wielkie, Leśnica, Łubniany, Murów, Olesno - obszar wiejski, Ozimek - obszar wiejski, Pawłowiczki, Pokój, Polska Cerkiew, Popielów, Prószków - obszar wiejski, Reńska Wieś, Strzelce Opolskie - obszar wiejski, Strzeleczki, Tarnów Opolski, Turawa, Ujazd, Walce, Zawadzkie - obszar wiejski, Zdzieszowice - obszar wiejski, Zębowice

Z kolei za gminy niemigracyjne (30), charakteryzujące się ograniczoną skalą emigracji zarobkowej uznano: Baborów - obszar wiejski, Branice, Byczyna - obszar wiejski, Domaszowice, Głogówek - obszar wiejski, Głubczyce - obszar wiejski, Głuchołazy - obszar wiejski, Grodków - obszar wiejski, Kamiennik, Kietrz - obszar wiejski, Korfantów - obszar wiejski, Lewin Brzeski - obszar wiejski, Lubrza - obszar wiejski, Lubsza - obszar wiejski, Łambinowice - obszar wiejski, Namysłów - obszar wiejski, Niemodlin - obszar wiejski, Nysa, - obszar wiejski, Olszanka, Paczków - obszar wiejski, Pakosławice, Praszka - obszar wiejski, Prudnik - obszar wiejski, Rudniki, Skarbimierz, Skoroszyce, Świerczów, Tułowice, Wilków, Wołczyn - obszar wiejski.

W dalszej części opracowania dokonano analizy danych pochodzących z Banku Danych Lokalnych odnoszących się do liczby osób fizycznych prowadzących działalność gospodarczą oraz liczby mieszkańców poszczególnych gmin wiejskich województwa opolskiego z podziałem na gminy wiejskie migracyjne i niemigracyjne oraz dokonano oceny wpływu emigracji zarobkowej na poziom aktywność gospodarczej.

\section{Emigracja zarobkowa a aktywność gospodarcza w świetle literatury oraz badań}

W polskiej oraz światowej literaturze przedmiotu relatywnie często podejmowane są rozważania na temat związku emigracji zarobkowej z działalnością gospodarczą i inwestycyjną. Zakłada się bowiem, że rozwojowi lokalnej przedsiębiorczości powinien służyć kapitał zgromadzony podczas pracy za granicą, a także nabyte w czasie wyjazdów kwalifikacje i umiejętności. W licznych analizach, przede wszystkim w angielskojęzycznej literaturze migracyjnej, pojawiają się dowody, że emigracja i związane z nią migracje powrotne mogą pobudzać przedsiębiorczość na terenach wiejskich stanowiących obszar pochodzenia migrantów. Potwierdzeniem mogą być badania przeprowadzone chociażby w Meksyku, które pokazują, że znaczna część migrantów podejmujących pracę w Stanach Zjednoczonych przeznacza środki na podjęcie działalności gospodarczej po powrocie do kraju pochodzenia (Agunias 2006, s. 27-34; Consulting i Sander 2003, s. 18; Escobar i Martinez 1990, s. 51; por. Cornelius 1990). O wpływie emigracji zarobkowej na rozwój przedsiębiorczości świadczą również wyniki badań z Albanii (Kule 1999, s. 20) oraz Maroka (Berriane 1992), z których wynika, że część kapitału potrzebnego do otwarcia działalności gospodarczej pochodzi ze środków uzyskanych dzięki pracy za granicą. Podobne prawidłowości dają się czasem zauważyć w Polsce, m.in. w dotkniętym migracjami województwie opolskim, gdzie wiele firm funkcjonuje dzięki kapitałowi i doświadczeniom uzyskanym podczas zarobkowego pobytu za granicą (Solga 2013, s.162-163).

Podejmowane są także badania na temat skłonności do inwestowania zarobionych za granicą środków w działalność gospodarczą na obszarach wiejskich. Wyniki badań dowodzą, że skłonność ta zależna jest od wielu czynników, a jednym z nich jest otoczenie lokalizacji przedsiębiorstw (Jasińska-Biliczak 2013, s. 326-336) oraz sprzyjające warunki do prowadzenia działalności rolniczej, np. lokalizacja w zasięgu oddziaływania aglomeracji (Durand i Massey 1992, s. 3). W literaturze przedmiotu (Haas 2007, s. 25) podkreśla się również, że częstotliwość lokowania oszczędności z migracji zarobkowej w tworzenie 
nowych przedsiębiorstw uzależniona jest od sytuacji gospodarczej na obszarach wiejskich oraz od dostępności finansowania zewnętrznego.

W polskiej literaturze migracyjnej dominują jednak opinie, że kapitał zgromadzony podczas pracy za granicą nie prowadzi do inwestycji rozwojowych, a w większości przypadków służy jedynie zaspokajaniu celów konsumpcyjnych. Należałoby w tym miejscu powołać się na badania prowadzone w gminie Perlejewo w województwie podlaskim w Polsce, gdzie zaobserwowano, że transfery z pracy za granicą były głównie przeznaczane na cele konsumpcyjne, nieprzynoszące dochodów w przyszłości (Hirszfel i Kaczmarczyk 1999, s. 31). Na negatywny wpływ migracji na aktywność gospodarczą wskazują również wyniki badań prowadzone w województwie opolskim (Jończy 2003, s. 209). Potwierdzają one, że w gminach wiejskich województwa, które charakteryzują się wysoką skalą emigracji zarobkowej mieszkańców występuje jednocześnie niski wskaźnik aktywności gospodarczej mieszkańców.

\section{Analiza dotycząca aktywności gospodarczej na migracyjnych i niemigracyjnych obszarach wiejskich województwa opolskiego}

Celem prezentowanej w niniejszym opracowaniu analizy było ustalenie związku pomiędzy natężeniem emigracji zarobkowej a aktywnością gospodarczą w gminach wiejskich województwa opolskiego. Posłużył temu wskaźnik liczby osób fizycznych prowadzących działalność gospodarczą na 100 mieszkańców w gminach migracyjnych i niemigracyjnych Opolszczyzny obliczony na podstawie danych zawartych w Banku Danych Lokalnych GUS (ryc. 1.). Porównanie wartości wskaźnika w obu wyodrębnionych grupach gmin wiejskich pokazuje, że aktywność gospodarcza jest nieco niższa w gminach migracyjnych $(5,3)$ aniżeli w gminach niemigracyjnych $(5,6)$. Może to świadczyć o niekorzystnym wpływie emigracji zarobkowej na aktywność gospodarczą.

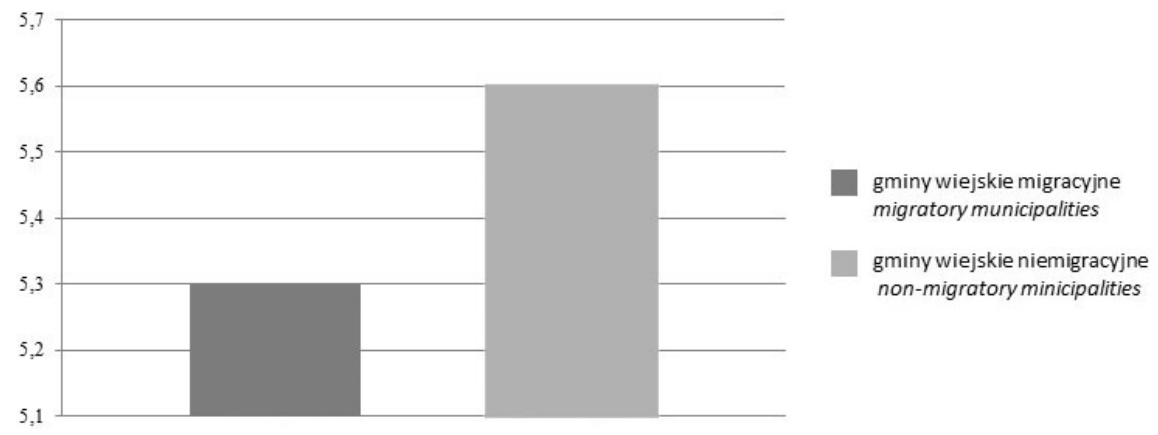

Ryc. 1. Wskaźnik liczby osób fizycznych prowadzących działalność gospodarczą na 100 mieszkańców gmin migracyjnych i niemigracyjnych województwa opolskiego Źródło: opracowanie własne.

Entrepreneurship activity indicator for rural migratory and non-migratory municipalities of the Opolskie Voivodship Source: own elaboration

O wpływie masowej migracji zarobkowej na aktywność gospodarczą przekonuje ponadto analiza wskaźnika aktywności gospodarczej w poszczególnych gminach migracyjnych i niemigracyjnych województwa opolskiego. Zestawienie wszystkich gmin wiejskich województwa według wartości tego wskaźnika zaprezentowano na ryc. 2. 


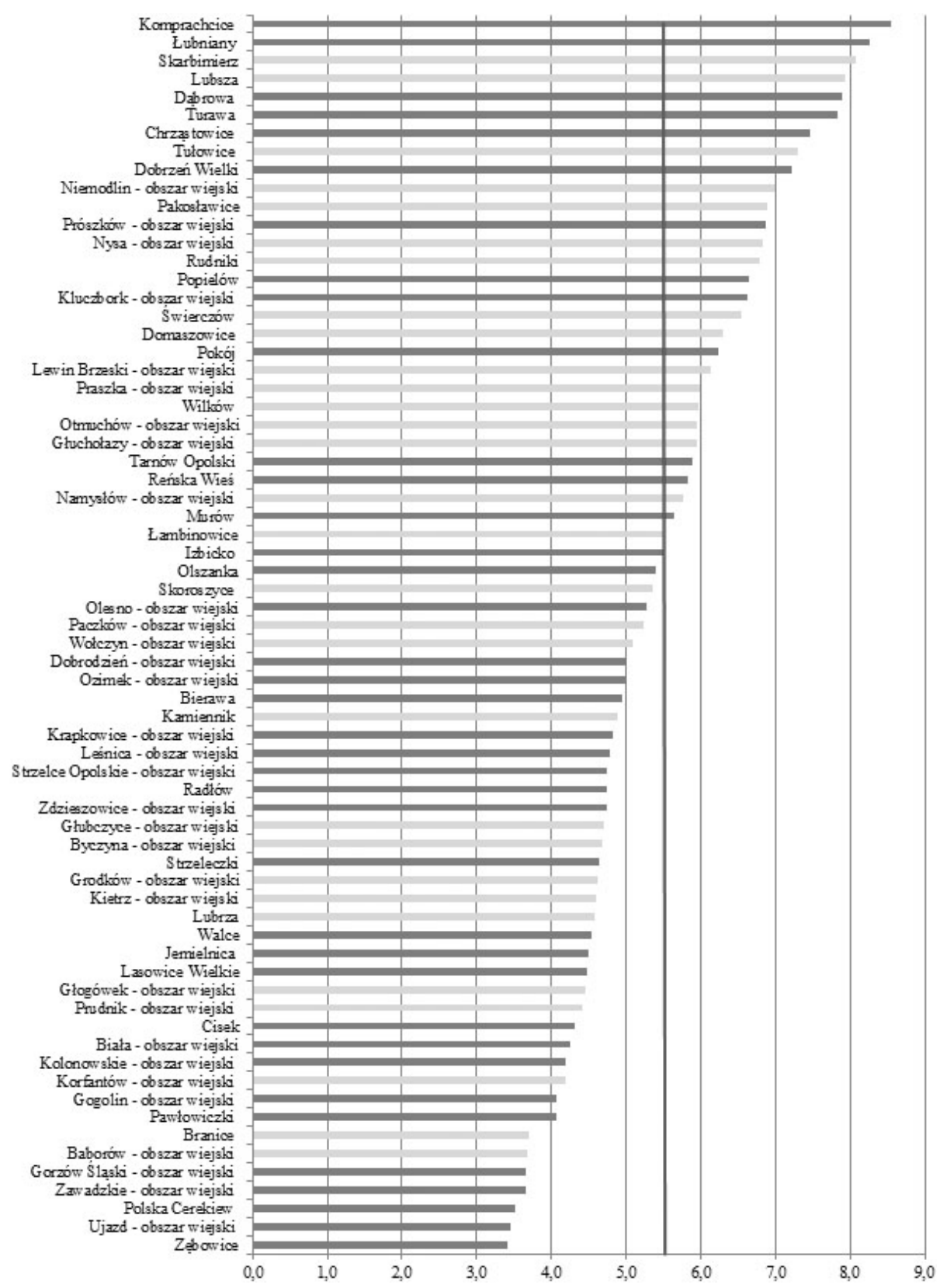

Ryc. 2. Wskaźniki aktywności gospodarczej mierzonej liczbą osób fizycznych prowadzących działalność gospodarczą na 100 mieszkańców w gminach wiejskich województwa opolskiego.

Gminy migracyjne - kolor ciemnoszary, gminy niemigracyjne - kolor jasnoszary, linia pionowa - średnia wartość wskaźnika dla wszystkich analizowanych gmin.

Źródło: opracowanie własne na podstawie danych GUS z Banku Danych Lokalnych.

Entrepreneurship activity indicator for rural migratory and non-migratory municipalities in the Opolskie Voivodship. Migratory municipalities - dark gray, non-migratory municipalities - light gray, vertical line - average indicator value for all rural municipalities.

Source: own elaboration based on CSO LDB data. 
Średnia wartość przyjętego wskaźnika aktywności gospodarczej dla wszystkich gmin wiejskich województwa opolskiego wynosi 5,5. Natomiast szczegółowa analiza zaprezentowanych na wykresie danych pozwala dostrzec prawidłowość, że w grupie gmin charakteryzujących się najmniejszymi wartościami wskaźnika dominują gminy migracyjne. Potwierdzeniem tego może być fakt, że w grupie gmin wiejskich, dla których wskaźnik aktywności gospodarczej przyjmuje wartości poniżej średniej dla wszystkich gmin wiejskich województwa opolskiego, znajduje się aż 22 gmin migracyjnych, a tylko 16 niemigracyjnych. Z kolei wśród gmin charakteryzujących się najwyższą wartością wskaźnika znacznie częściej pojawiają się gminy niemigracyjne - w grupie, dla których wartość wskaźnika aktywności gospodarczej przyjmuje wartości powyżej średniej, znajduje się 13 gmin migracyjnych oraz 17 niemigracyjnych. Ponadto na negatywne oddziaływanie emigracji zarobkowej na aktywność gospodarczą może wskazywać fakt, że najniższe wartości wskaźnika spośród wszystkich gmin wiejskich województwa opolskiego odnotowano dla pięciu gmin migracyjnych: Zębowice, Ujazd, Polska Cerekiew, Zawadzkie oraz Gorzów Śląski. Dane te zdają się potwierdzać przypuszczenie o oddziaływaniu emigracji zarobkowej na niższą aktywność gospodarczą.

Warto jednak zwrócić uwagę na inny jeszcze poza emigracją zarobkową istotny czynnik decydujący o aktywności gospodarczej w gminach wiejskich województwa. Otóż wskazane gminy migracyjne charakteryzujące się najniższą wartością wskaźnika aktywności gospodarczej to także gminy położone peryferyjnie, w znacznej odległości od miasta wojewódzkiego oraz innych większych miast w regionie. W tym przypadku czynnikiem decydującym o niskiej aktywności gospodarczej mieszkańców może okazać się, oprócz znacznej skali emigracji zarobkowej - peryferyjne położenie gmin. Z kolei jedne z wyższych wartości przyjętego wskaźnika aktywności gospodarczej odnotowano także w gminach migracyjnych, takich jak: Komprachcice, Łubniany, Dąbrowa, Turawa i Chrząstowice. W tym przypadku wydaje się, że na wysokość przyjętych wskaźników może oddziaływać lokalizacja gmin w pobliżu miasta wojewódzkiego będącego jednym z najbardziej atrakcyjnych rynków zbytu w całym województwie.

\section{Podsumowanie}

Niezwykle trudno jest jednoznacznie odpowiedzieć na pytanie o kierunek oddziaływania emigracji zarobkowej na aktywność gospodarczą. Z jednej strony można przytoczyć argumenty za pozytywnym jej wpływem na aktywność gospodarczą. Taki efekt może być rezultatem napływu transferów z pracy za granicą do lokalnej lub regionalnej gospodarki oraz związanego z tym większego popytu wpływającego na większą liczbę przedsiębiorstw. Kolejnym argumentem potwierdzającym pozytywne oddziaływanie emigracji na aktywność gospodarczą jest proces reemigracji oraz powiązany z nim wpływ wykorzystania zdobytego za granicą kapitału w kraju pochodzenia migrantów powrotnych na zakładanie działalności gospodarczej. Z drugiej strony, emigracja zarobkowa mieszkańców prowadzić może do mniejszej aktywności gospodarczej obszarów dotkniętych intensywnymi wyjazdami zagranicznymi z uwagi na „wypłukiwanie” się regionu z osób przedsiębiorczych, z zasobów pracy oraz konsumentów, co w konsekwencji prowadzić może do ograniczenia aktywności gospodarczej w miejscu pochodzenia migrantów. Do takich wniosków - niekorzystnego oddziaływania emigracji zarobkowej na aktywność gospodarczą na obszarach wiejskich 
województwa opolskiego - prowadzić może zaprezentowana analiza. Potwierdziła ona, że gminy migracyjne charakteryzują się nieco mniejszym wskaźnikiem aktywności gospodarczej $(5,3)$ aniżeli gminy niemigracyjne $(5,6)^{3}$, ponadto w gminach migracyjnych odnotowano najniższe wskaźniki aktywności gospodarczej spośród wszystkich gmin wiejskich województwa opolskiego.

Jednocześnie należy pamiętać, że na zakłócenie wyników prezentowanej analizy mogło wpłynąć kilka czynników. Po pierwsze, bardzo istotnym czynnikiem wpływającym na aktywność gospodarczą jest lokalizacja gminy w pobliżu większych miast regionu. Wskazuje na to wysoka wartość wskaźnika w niektórych gminach o charakterze migracyjnym położonych w bezpośrednim sąsiedztwie miasta wojewódzkiego. Z kolei w przypadku gmin położonych peryferyjnie w stosunku do większych miast, wskaźniki aktywności gospodarczej przyjmują najniższe wartości. Po drugie, jak dowodzą prowadzone na Opolszczyźnie badania, zwłaszcza w gminach zaliczanych do gmin migracyjnych zamieszkałych przez ludność rodzimą Śląska, odnotowuje się znaczną skalę zjawiska emigracji zawieszonej. Prowadzi ona do zniekształcenia danych meldunkowych, co w konsekwencji powoduje zdeformowanie przyjętych wskaźników per capita (Dybowska 2013; Jończy i Rokita 2008). W przypadku niektórych miejscowości w gminach migracyjnych skala emigracji zawieszonej osiąga nawet poziom 25\%, co może zawyżać wartość mianownika wskaźnika aktywności gospodarczej i jednocześnie sztucznie zaniżać wartość samego wskaźnika.

Wspomniane wątpliwości sprawiają, że niezwykle trudno jest jednoznacznie wykazać wpływ emigracji zarobkowej na aktywność gospodarczą w ogóle, a jeszcze trudniej wpływ ten określić w przypadku gmin wiejskich województwa opolskiego z uwagi na skalę emigracji zawieszonej, mimo że analiza przyjętego wskaźnika aktywności gospodarczej opartego na danych statystycznych taki niekorzystny wpływ potwierdza.

\section{Literatura}

Agunias D.R., 2006, Remittances and Development: Trends, Impacts, and Policy Options. A Review of the Literature, Migration Policy Institute, Washington. Publikacja dostępna na stronie www. migrationpolicy.org

Berriane M., 1992, Emigration internationale du travail et mirco-urbanisationdans le rif oriental: Cas du centre de Taouima (Région de Nador, Maroc), Publications de la Faculté des Lettres et des Sciences Humaines de Rabat, Universite de Tunis, Tunis.

Consulting B., Sander C., 2003, Migrant remittances to developing countries, a scope study: overview and introduction to issues for pro-poor financial services, UK Department of International Development, London.

Cornelius W., 1990, Labor Migration to the United States: Development Outcomes and Alternatives in Mexican Sending Communities, Commission for the Study of International Migration and Cooperative Economic Development, Washington, DC.

${ }^{3}$ Do podobnych wniosków dotyczącej wpływu emigracji zarobkowej na aktywność gospodarczą w społecznościach wiejskich doprowadziła analiza zaprezentowana w rozprawie doktorskiej autorki. W jej wyniku okazało się, że w wybranych do badań wiejskich miejscowościach migracyjnych przyjęty wskaźnik aktywności gospodarczej wynosił 2,66, a w miejscowościach niemigracyjnych 3,25.

4 Emigracja zawieszona przez niektórych badaczy określana jako emigracja niepełna związana jest z faktem, że pewna część społeczeństwa opuściła na stałe swoje poprzednie miejsce zamieszkania, nie dokonując jednocześnie wymeldowana z pobytu stałego. 
Durand J., Massey D.S., 1992, Mexican Migration to the United States: A Critical Review, Latin American Research Review, 27, 3, s. 3.

Dybowska J., 2013, Przemiany demograficzne w regionie o nasilonej migracji zagranicznej na przykładzie województwa opolskiego, Uniwersytet Opolski.

Escobar A., de la O Martinez M., 1990, Small-scale Industry and International Migration in Guadalajara, Mexico, Commission for the Study of International Migration and Cooperative Economic Development, Washington.

Haas H. de, 2007, Remittances, Migration and Social Development: a Conceptual View of the Literature, Social Policy and Development Programme Paper, 34, s. 25.

Hirszfeld Z., Kaczmarczyk P., 1999, Ekonomiczne i społeczne skutki migracji na poziomie mikrospołecznym, Prace Migracyjne, 21, Instytut Studiów Społecznych, Uniwersytet Warszawski, Warszawa, s. 31.

Iglicka-Okólska K., 1998, Analiza zachowań migracyjnych na podstawie wyników badania etnosondażowego migracji zagranicznych w wybranych regionach Polski w latach 1975-1994, Szkoła Główna Handlowa, Warszawa.

Jasińska-Biliczak A., 2012, Sektor małych i średnich przedsiębiorstw województwa opolskiego na tle polityki regionalnej Unii Europejskiej, [w:] G. Ślusarz (red.), Nierówności społeczne a wzrost gospodarczy, Determinanty rozwoju regionalnego kontekście procesów globalizacji, 28, Rzeszów, s. $326-336$

Jończy R., 2010, Migracje zagraniczne z obszarów wiejskich województwa opolskiego po akcesji Polski do Unii Europejskiej. Wybrane aspekty ekonomiczne i demograficzne, Opole-Wrocław.

Jończy R., 2003, Migracje zarobkowe ludności autochtonicznej z województwa opolskiego. Studium ekonomicznych determinant i konsekwencji, Uniwersytet Opolski, Opole.

Jończy R., Rokita D., 2008, Wpływ transferu zarobków z zagranicy na poziom dobrobytu materialnego i konsumpcji w województwa opolskim, [w:] W. Caban (red.), Globalizacja przyczynq ubożenia podatkowego państwa?, Wyższa Szkoła Finansów i Informatyki, Kalisz.

Klemens B., 2014, Jakość życia na obszarach wiejskich Ślqaska ze szczególnym uwzględnieniem uwarunkowań demograficznych, Studia Śląskie, t. LXXIV, Opole, s. 105-106.

Kule D., 1999, The Causes and Consequences of Albanian Emigration during Transition: Evidence from Micro-data, University of Tirania, Tirana.

Latuch M., 1985, Demografia społeczno-ekonomiczna, PWE, Warszawa.

Okólski M., 2011, Modernizacyjna rola migracji, CMR Working Papers, 46/(104), s. 16.

Poskart R., 2013, Usługi bankowe zwiq̨zane z transferem w obrocie prywatnym środków pieniężnych z zagranicy do Polski, [w:] E. Bogacka-Kisiel (red.), Nauki o Finansach, 1 (14), s. 195.

Rauziński R., Szczygielski K., 2008, Śląska ludność rodzima w strukturze demograficznej i społecznej Śląska Opolskiego wczoraj i dziś, Wyższa Szkoła Zarządzania i Administracji w Opolu, Opole.

Solga B., 2013, Miejsce i znaczenie migracji zagranicznych w rozwoju regionalnym, Politechnika Opolska, Opole.

Wpływ emigracji zarobkowej na gospodarkę Polski, 2007, Ministerstwo Gospodarki, Warszawa. 


\section{Summary}

Rural areas in the Opolskie Voivodship have experienced a number of changes over the past few decades, which have had a significant impact on their current socio-economic situation. One of the factors which could have the crucial importance in this process includes intense external migration of significant share of region's population. In the past the migration was mainly generated by those inhabitants, who due to dual citizenship - Polish and German were eligible to work in Western Europe before Poland's accession to the European Union. In the face of the migration in rural areas of the Opolskie Voivodship there have been observed significant demographic, social and economic transformation. Having regard to the above, the purpose of the article is to present the comparative analysis concerning out-migration impact on economic activity in the rural areas of the Opolskie Voivodship. The economic activity was measured by the number of individuals engaged in business activity per 100 inhabitants. As a result, it was found that emigration may be related to the economic activity of rural population, although it can be determined by a number of other factors. 
http://rcin.org.pl 